\title{
DEFINING OPTIMAL WAYS OF KHARKIV`S SOCIAL-ECONOMIC DEVELOPMENT BY COMPONENT ANALYSIS
}

\begin{abstract}
А. В. МаЗУрова. ВИЗНАЧЕННЯ ШЛЯХІВ ОПТИМІЗАЦІЇ СОЦІАЛЬНО-ЕКОНОМІЧНОГО РОЗВИТКУ ТА ОРГАНІЗАЦІЇ МІСЬКОГО ПРОСТОРУ ХАРКОВА НА ОСНОВІ КОМПОНЕНТНОГО АНАЛЗУ. У статті охарактерИзовано метод компонентного аналізу, який полягає у визначенні проекиій вектору розвитку на кожну вісь багатовимірного ознакового простору із детальним змістовним аналізом їх змін. Представлена динаміка індексів статистичних параметрів соціогеосистеми міста Харкова та окремо ії районних соиіогеосистем за період з 2010 по 2015 рр. Визначені показники, щзо позитивно та негативно впливали на розвиток сочіогеосистеми міста Харкова загалом та окремо для кожного адміністративного району. Серед показників позитивного впливу можна виділити: збільшення чисельності дітей у дошкільних та загальноосвітніх закладах, зростання обсягів реалізованої промислової продукції, збільшення кількості суб'єктів ЄДРПОУ, зменшення використання котельно-пічного палива та зменшення використання теплоенергії. Зменшення кількості населення; зменшення кількості загальноосвітніх закладів; зменшення студентів у BHЗ I-II та III-IV рівнів акредитації; зменшення чисельності працівників, що займаються науковою діяльністю відносимо до показників негативного впливу. Визначені райони-лідери та райони-аутсайдери за темпами сочіально-економічного розвитку. За динамікою розвитку провідними районами стали Шевченківський та Індустріальний райони, райони-аутсайдери - Немишлянський та Київький райони. Запропоновані рекомендачії щодо оптимізачії розвитку для кожного з районів міста та міста загалом.

Ключові слова: компонентний аналіз, сочіально-економічний розвиток, соиіогеосистема, статистичні показники,
\end{abstract} організація міського простіру, місто Харків, адміністративні райони міста Харкова.

А. В. Мазурова. ВИЗНАЧЕННЯ ШЛЯХІВ ОПТИМІЗАЦІЯ СОЦАЛЬНО-ЕКОНОМІЧНОГО РОЗВИТКУ ТА ОРГАНІЗАЦЇ̈ МІСБКОГО ПРОСТОРУ ХАРКОВА НА ОСНОВІ КОМПОНЕНТНОГО АНАЛІЗУ. В статье охарактеризован метод компонентного анализа, который заключается в определении проекиий вектора развития на каждую ось многомерного признакового пространства с подробным содержательным анализом их изменений. Представлена динамика индексов статистических параметров сочиогеосистемы города Харькова и отдельно ее районных сочиогеосистем за период с 2010 по 2015г2. Определены показатели, которые положительно и отрицательно влияли на развитие социогеосистемы города Харькова в иелом и отдельно для каждого административного района. Среди показателей положительного влияния можно выделить: увеличение численности детей в дошкольных и общеобразовательных учреждениях, рост объемов реализованной промышленной продукции, увеличение количества субъектов ЕГРПОУ, уменьшение использования котельно-печного топлива и уменьшения использования теплоэнергии. Уменьшение количества населения; уменьшение количества общеобразовательных учреждений; уменьшение количества студентов в вузах III и III-IV уровней аккредитации; уменьшение численности работников, занимающихся научной деятельностью относим к показателям негативного воздействия. Определены районы-лидеры и районы-аутсайдеры по темпам соичально-экономического развития. По динамике развития ведущими районами стали Шевченковский и Индустриальный районы, районы-аутсайдеры - Немышлянский и Киевский районы. Предложенные рекомендаџии по оптимизачии развития для каждого из районов города и города в иелом.

Ключевые слова: компонентный анализ, сочиально-экономическое развитие, сочиогеосистема, статистические показатели, организация городского пространства, город Харьков, административные районы города Харькова.

Introduction. Due to active development of the Ukrainian cities problems and prospects of urban organization, ways of city space`s optimization need to be determined. For Kharkiv city, the second biggest city by population in Ukraine, the leading industrial, scientific and cultural center of the state, question of weaknesses and strengths of development is quite relevant.

The purpose of article to define optimal directions of social and economic development and organization of Kharkiv city space on the basis of the component analysis.

The main part of the study. In order to identify and characterize dynamics of urban space development, it is necessary to carefully investigate changes in social geographical system (SGS) of the city in general and its administrative parts, city districts, over a certain period of time in a multidimensional space (MS). In this article we have used a component analysis of vector development, proposed by Niemets $\mathrm{K}$. and Niemets L. and others [1, 6-9, 17-19].
The essence of this method is definition of development vector projections to MS with the detailed substantial analysis of their changes. This allows us to move from general assessment of the conditions and level of SGS`s development in an integral form to the assessment of individual components (parameters). The results can be used to solve such tasks as planning, forecasting and optimizing development, as well as managing, for example, in the context of sustainable development concept implementation. For such tasks, it is necessary to know the fate ("contribution") of each parameter in the overall development of SGS and to find the "vulnerable" places of this process for precise intervention.

From mathematical position this task is reduced to calculation of time derivatives of each parameter in the corresponding process for a certain period and has two variants of a solution. There are qualitative and quantitative variants. The qualitative solution is reduced only to the definition of the time derivative sign (increases, decreases or remains unchanged). A quantitative solution involves determining not only 
the sign, but also the value of the derivative, which gives a more accurate assessment of the event on the relative scale. This work is limited to the analysis of exclusively qualitative problem-solving, as the most general.

There are three possible results of calculating time derivatives:

1) if the parameter remained unchanged during the calculation period (the process is stable), the derivative is 0 ;

2) if the parameter decreases (the process returns to it), the derivative is negative (code -1);
3 ) if the parameter increases (the process progresses after it), the derivative is positive (code +1$)$.

Concrete recommendations as to how improve organization of Kharkiv city space can be obtained by analyzing changes in the indexes of statistical parameters of various spheres of the city life. A database of 51 indicators describing organization of Kharkiv city space and its general socio-economic development was constructed and processed (Table 1). Such an analysis was performed for all district sociogeosystems of Kharkiv and, in general, for the city. Table 1 shows the dynamics of parameter change for all study periods (from 2010 to 2015).

Table 1

Dynamics of changes in the indexes of statistical parameters of Kharkiv`s urban SGS by estimated periods (calculated and constructed by the author according to [2-5, 10-15])

\begin{tabular}{|c|c|c|c|c|c|c|}
\hline Statistical parameters & $\begin{array}{c}2010- \\
2011\end{array}$ & $\begin{array}{l}2011- \\
2012\end{array}$ & $\begin{array}{l}2012- \\
2013 \\
\end{array}$ & $\begin{aligned} 2013- \\
2014\end{aligned}$ & $\begin{array}{l}2014- \\
2015\end{array}$ & codes \\
\hline Number of officially registered enterprises / units & 9 & 9 & 0 & 9 & 9 & 36 \\
\hline Number of children $/ \mathrm{k}$ & 9 & 7 & 6 & 9 & 4 & 35 \\
\hline Number of students / $\mathrm{k}$ & 9 & 1 & 4 & 9 & 9 & 32 \\
\hline Volume of sold industrial products / mln UAH & 7 & 5 & 3 & 7 & 9 & 31 \\
\hline Volume of sold industrial production / UAH / per. & 7 & 5 & 3 & 7 & 9 & 31 \\
\hline Natural increase of population / \%o & 5 & 2 & 2 & 9 & 9 & 27 \\
\hline Natural increase of population / per. & 6 & 1 & 1 & 9 & 9 & 26 \\
\hline Number of deceased / per. & 9 & -7 & 5 & 7 & 9 & 23 \\
\hline Number of deceased / \%o & 7 & -5 & 4 & 7 & 9 & 22 \\
\hline Number of births / \%o & 0 & 5 & -2 & 9 & 9 & 21 \\
\hline Number of births / per. & -1 & 5 & -3 & 9 & 9 & 19 \\
\hline General migration / per. & -5 & 9 & -5 & 9 & 9 & 17 \\
\hline Volume of realized innovative products / $\mathrm{k}$ UAH & 1 & 5 & 1 & 3 & 7 & 17 \\
\hline Commissioning of residential buildings $/ \mathrm{k} \mathrm{m}^{2}$ & -3 & 1 & 7 & 5 & 6 & 16 \\
\hline Pre-school establishments / units & 3 & 4 & 4 & 2 & 1 & 14 \\
\hline Number of marriages / units & 5 & -9 & 9 & 7 & 1 & 13 \\
\hline Putting into operation of an individual dwelling / $\mathrm{km}^{2}$ & -7 & 9 & 3 & 4 & 4 & 13 \\
\hline Number of marriages / \%o & 5 & -9 & 9 & 5 & 1 & 11 \\
\hline Migration balance / per. & -3 & 7 & -7 & 9 & 5 & 11 \\
\hline Passenger transportation / $\mathrm{k}$ units & -1 & -1 & -3 & 9 & 7 & 11 \\
\hline Volume of realized services to the population / $\mathrm{k}$ UAH & 3 & 5 & 1 & 3 & -1 & 11 \\
\hline Freight / kt & 1 & -5 & 1 & 7 & 5 & 9 \\
\hline $\begin{array}{l}\text { Putting individual residential buildings / units into op- } \\
\text { eration }\end{array}$ & -7 & 9 & 1 & 6 & -1 & 8 \\
\hline Number of divorces / \%o & 9 & 8 & -2 & -5 & -3 & 7 \\
\hline Children's health and recreation facilities / units & -2 & 1 & 3 & 3 & 2 & 7 \\
\hline $\begin{array}{l}\text { Commissioning of residential buildings unit. multi- } \\
\text { apartment building }\end{array}$ & -7 & 9 & 1 & 4 & 0 & 7 \\
\hline The number of children who rested in the summer / per. & -5 & 1 & 8 & -2 & 4 & 6 \\
\hline Number of divorces / units & 9 & 9 & -3 & -7 & -3 & 5 \\
\hline Number of Innovative Enterprises / units & -4 & 6 & 2 & -1 & 2 & 5 \\
\hline New technological processes / units & -5 & 5 & -2 & 2 & 4 & 4 \\
\hline $\begin{array}{l}\text { Volume of scientific and scientific work performed / } \\
\text { k UAH }\end{array}$ & 1 & 3 & -1 & 2 & -1 & 4 \\
\hline Foreign direct investment / $\mathrm{k}$ dollars USA & 3 & 5 & 3 & 1 & -9 & 3 \\
\hline Cinemas / units & 1 & -1 & 2 & 0 & 0 & 2 \\
\hline Organizations conducting scientific and scientific- & -4 & 1 & -1 & 3 & 3 & 2 \\
\hline
\end{tabular}




\begin{tabular}{|l|c|c|c|c|c|c|}
\hline technical work / units. & & & & & & \\
\hline Electricity usage / million kWh & 7 & -7 & -3 & 0 & 5 & $\mathbf{2}$ \\
\hline Foreign direct investment / k dollars USA/per. & 3 & 5 & 1 & 1 & -9 & $\mathbf{1}$ \\
\hline $\begin{array}{l}\text { Higher educational institutions of I-II levels of accredi- } \\
\text { tation / units }\end{array}$ & 0 & 0 & 0 & 0 & 0 & $\mathbf{0}$ \\
\hline $\begin{array}{l}\text { Higher educational establishments of III-IV accredita- } \\
\text { tion levels / units }\end{array}$ & 0 & 0 & 0 & 0 & 0 & $\mathbf{0}$ \\
\hline Number of theaters / units & 0 & 0 & 0 & 0 & 0 & $\mathbf{0}$ \\
\hline Number of clubs / units & 0 & 0 & 0 & 1 & -1 & $\mathbf{0}$ \\
\hline $\begin{array}{l}\text { Putting into operation hospital and outpatient clinics } \\
\text { (beds) / units }\end{array}$ & 0 & 0 & 1 & -1 & 0 & $\mathbf{0}$ \\
\hline Museums / units & 0 & -1 & 0 & 0 & 0 & $\mathbf{- 1}$ \\
\hline $\begin{array}{l}\text { Students of higher education institutions I-II levels of } \\
\text { accreditation / k per. }\end{array}$ & -4 & -5 & 0 & 3 & 4 & $\mathbf{- 2}$ \\
\hline $\begin{array}{l}\text { Students of higher education institutions III-IV accredi- } \\
\text { tation levels / k units }\end{array}$ & -1 & -6 & -5 & 5 & 5 & $\mathbf{- 2}$ \\
\hline $\begin{array}{l}\text { Number of employees of (scientific and technical) ac- } \\
\text { tivity / per. }\end{array}$ & -5 & -5 & -9 & 9 & 5 & $\mathbf{- 5}$ \\
\hline $\begin{array}{l}\text { Emissions of pollutants into the air from stationary } \\
\text { sources / kt }\end{array}$ & -2 & -3 & 3 & -4 & 1 & $\mathbf{- 5}$ \\
\hline General educational establishments / units & -3 & 1 & -2 & -2 & 0 & $\mathbf{- 6}$ \\
\hline Population / per. & -9 & -5 & -1 & 3 & 3 & $\mathbf{- 9}$ \\
\hline General migration / per. & 3 & -9 & -3 & -3 & -3 & $\mathbf{- 1 5}$ \\
\hline Use of boiler-oven fuel / k conventional fuel & -1 & -7 & -7 & 1 & -1 & $\mathbf{- 1 5}$ \\
\hline Use of heat energy / k gcal & -1 & -9 & -9 & -7 & -9 & $\mathbf{- 3 5}$ \\
\hline Total numbe of codes & $\mathbf{4 2}$ & $\mathbf{4 9}$ & $\mathbf{2 0}$ & $\mathbf{1 6 6}$ & $\mathbf{1 3 7}$ & \\
\hline
\end{tabular}

During the investigated period, development of Kharkiv`s SGS was positively influenced by the following factors:

- increase in the number of children at preschool and educational institutions;

- growth of volumes of sold industrial products;

- increase in the number of officially registered enterprises;

- boiler-burning fuel use decrease ;

- use of heat decrease .

The negative consequence of Kharkiv`s SGS development was:

- reduction in population;

- reduction in general educational institutions;

- reduction of students in higher education institutions of I-II and III-IV accreditation levels;

- reduction in the number of employees engaged in scientific activities.

In the last investigated period from 2014-2015, demographic indicators, including birth rates, natural growth, and general migration, have significantly increased. Also indicators of business and industry (volume of sold industrial production and number of officially registered enterprises) have increased. Negative dynamics of development is characteristic of an indicator of direct investments and use of heat power.

The dynamics of changes in statistical indicators depicts the main trends of the city development
(Fig. 1). From 2010 to 2012 there was progressive development, period 2012-2013 was characterized by a decrease in the indicators (from 49 to 20 units). From 2013 to 2014, there was a marked increase in all indicators, namely an increase in the number of codes by 8 times (from 20 to 166 units). The indicated jump in statistical indicators is explained by the positive results of the Euro-2012 football championship, which influenced the development of the city's infrastructure and its socio-economic situation. The period from 2014 to 2015 was characterized by a slight decrease in the total number of indices. The decrease is due to the beginning of hostilities on the territory of the eastern states. Thus, the most progressive period was 2013-2014.

Analyzing changes of the indicator's sums it is possible to notice that for each regional SGS characteristic there are some development features. Improvement of demographic indicators is characteristic of one group of districts (table 2). There are Shevchenkivskyi and Osnovianskyi districts. Deterioration in the demographic sphere is characteristic for Kholodnohirskyi, Novobavarskyi and Slobidskyi districts.

Novobavarskyi, Kyivskyi, Slobidskyi, Kholodnohirskyi and Moskovskyi districts are characterized by active industrial and enterprise development, in particular the growth in the number of officially registered enterprises and volume of sold industrial and 


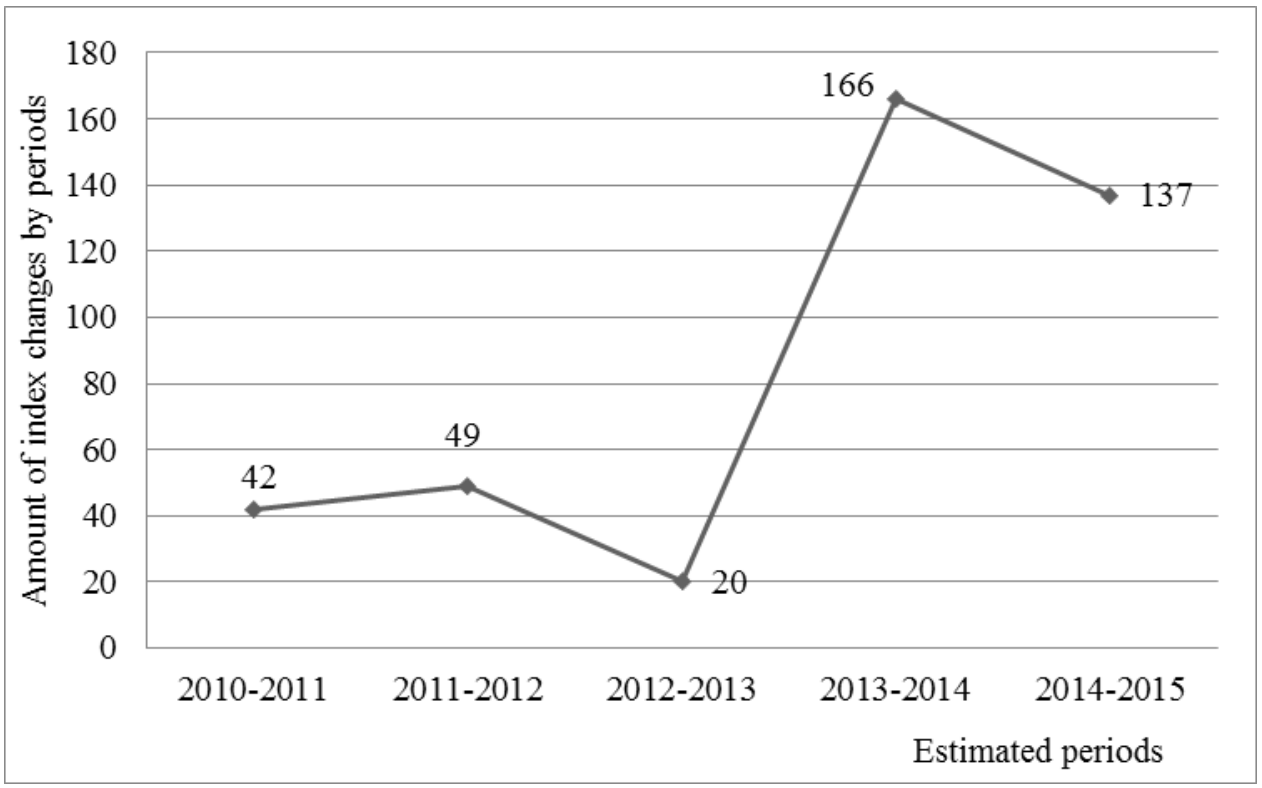

Fig. 1. Changes in statistical parameters index, SGS of Kharkiv city's district development

(calculated and constructed by the author according to [2-5, 10-15])

Table 2

Districts of Kharkiv city and indicators with significant growth and reduction

(constructed by the author according to component analysis)

\begin{tabular}{|c|c|c|c|}
\hline № & District & Significant growth & Significant reduction \\
\hline 1. & Shevchenkivskyi & $\begin{array}{l}\text { - Number of births, } \\
\text { - Natural growth of population, } \\
\text { - Number of pupils in secondary schools }\end{array}$ & $\begin{array}{l}\text { - use of heat, } \\
\text { - Foreign direct investment, } \\
\text { - Number of educational institu- } \\
\text { tions (schools) }\end{array}$ \\
\hline 2. & Novobavarskyi & $\begin{array}{l}\text { - Number of officially registered enter- } \\
\text { prises, } \\
\text { - Number of children (pre-school estab- } \\
\text { lishments) }\end{array}$ & $\begin{array}{l}\text { - Use of heat energy, } \\
\text { - Number of population, } \\
\text { - Number of students, } \\
\text { - Use of electricity }\end{array}$ \\
\hline 3. & Kyivskyi & $\begin{array}{l}\text { - Volume of sold industrial production } \\
\text { per person, } \\
\text { - Volume of sold industrial products, } \\
\text { - Number of officially registered enter- } \\
\text { prises, } \\
\text { - Number of children (pre-school estab- } \\
\text { lishments), } \\
\text { - Number of deceased }\end{array}$ & $\begin{array}{l}\text { - Number of educational institu- } \\
\text { tions (schools), } \\
\text { - Volume of sold services to the } \\
\text { population, } \\
\text { - Use of boiler-burning fuel }\end{array}$ \\
\hline 4. & Slobi & $\begin{array}{l}\text { - Volume of sold innovative products, } \\
\text { - Volume of sold industrial products, } \\
\text { - Volume of sold industrial products, } \\
\text { - General migration, } \\
\text { - Number of students }\end{array}$ & $\begin{array}{l}\text { - Number of population, } \\
\text { - Use of heat energy, } \\
\text { - Number of students, } \\
\text { - Use of electricity }\end{array}$ \\
\hline 5. & Kholodnohirskyi & $\begin{array}{l}\text { - Freight, } \\
\text { - Volume of sold industrial products, } \\
\text { - Volume of implemented services to } \\
\text { the population }\end{array}$ & $\begin{array}{l}\text { - Number of population, } \\
\text { - General migration, } \\
\text { - Number of employees of the } \\
\text { scientific and technical activities, } \\
\text { - Use of heat energy }\end{array}$ \\
\hline 6. & Moskovskyi & $\begin{array}{l}\text { - Number of officially registered enter- } \\
\text { prises, } \\
\text { - Number of children (pre-school estab- } \\
\text { lishments) }\end{array}$ & $\begin{array}{l}\text { - Total migration, } \\
\text { - Volume of scientific and scien- } \\
\text { tific work performed, } \\
\text { - Use of heat energy }\end{array}$ \\
\hline
\end{tabular}




\begin{tabular}{|c|c|c|c|}
\hline 7. & Industrialnyi & $\begin{array}{l}\text { - Number of new hospital and ambulato- } \\
\text { ry clinics } \\
\text { - Number of children (pre-school estab- } \\
\text { lishments) } \\
\text { - Number of students }\end{array}$ & $\begin{array}{l}\text { - Total migration, } \\
\text { - Number of introduced new } \\
\text { technological processes }\end{array}$ \\
\hline 8. & Nemyshlianskyi & $\begin{array}{l}\text { - Use of heat energy } \\
\text { - Number of children resting in the } \\
\text { summer } \\
\text { - Use of boiler-burning fuel }\end{array}$ & $\begin{array}{l}\text { - Number of officially registered } \\
\text { enterprises } \\
\text { - Number of students }\end{array}$ \\
\hline 9. & Osnovianskyi & $\begin{array}{ll}\text { - } & \text { Use of heat energy } \\
\text { - } & \text { General migration all exits } \\
\text { - } & \text { Number of population } \\
\text { - } & \text { Foreign direct investment }\end{array}$ & $\begin{array}{l}\text { - Number of officially registered } \\
\text { enterprises } \\
\text { - Number of students } \\
\text { - Number of children (pre-school } \\
\text { establishments) }\end{array}$ \\
\hline
\end{tabular}

innovative products. Foreign direct investment in Slobidskyi district has increased significantly. The health sector has improved in the Industrialnyi region by increasing the number of hospital and outpatient clinics.

The distribution of Kharkiv`s SGSs by the sum of indexes indicates a significant differentiation in the development dynamics among them. Thus, the leading regions according to development dynamics are Shevchenkivskyi (63) and Industrialnyi (55) (Fig. 2).

Rapid development of Shevchenkivskyi district was influenced by the improvement of demographic and economic indicators (increase of population, natural growth, officially registered enterprises etc.). Outsider districts by dynamics of development were Nemyshlianskyi (33) and Kyivskyi (23) districts. The greatest impact on the slowdown in the devel- opment of Kyivskyi region had reduction in the volume of services to the population, the volume of scientific and scientific work, number of education institutions. No spatial patterns of territorial differentiation were found (Fig. 3).

Later these calculations were used to formulate recommendations on optimizing the socio-economic and spatial development of Kharkiv city.

Demographic problems, in particular, the reduction of the population (children of preschool age, schoolchildren, youth) are typical for Novobavarskyi, Slobidskyi, Kholodnohirskyi, Osnovianskyi and Nemyshlianskyi districts. For these districts, it is proposed to introduce programs for improving the demographic situation. For example, to increase additional payments for the birth of a child and its maintenance, develop a network of establishments for children of school and preschool age.

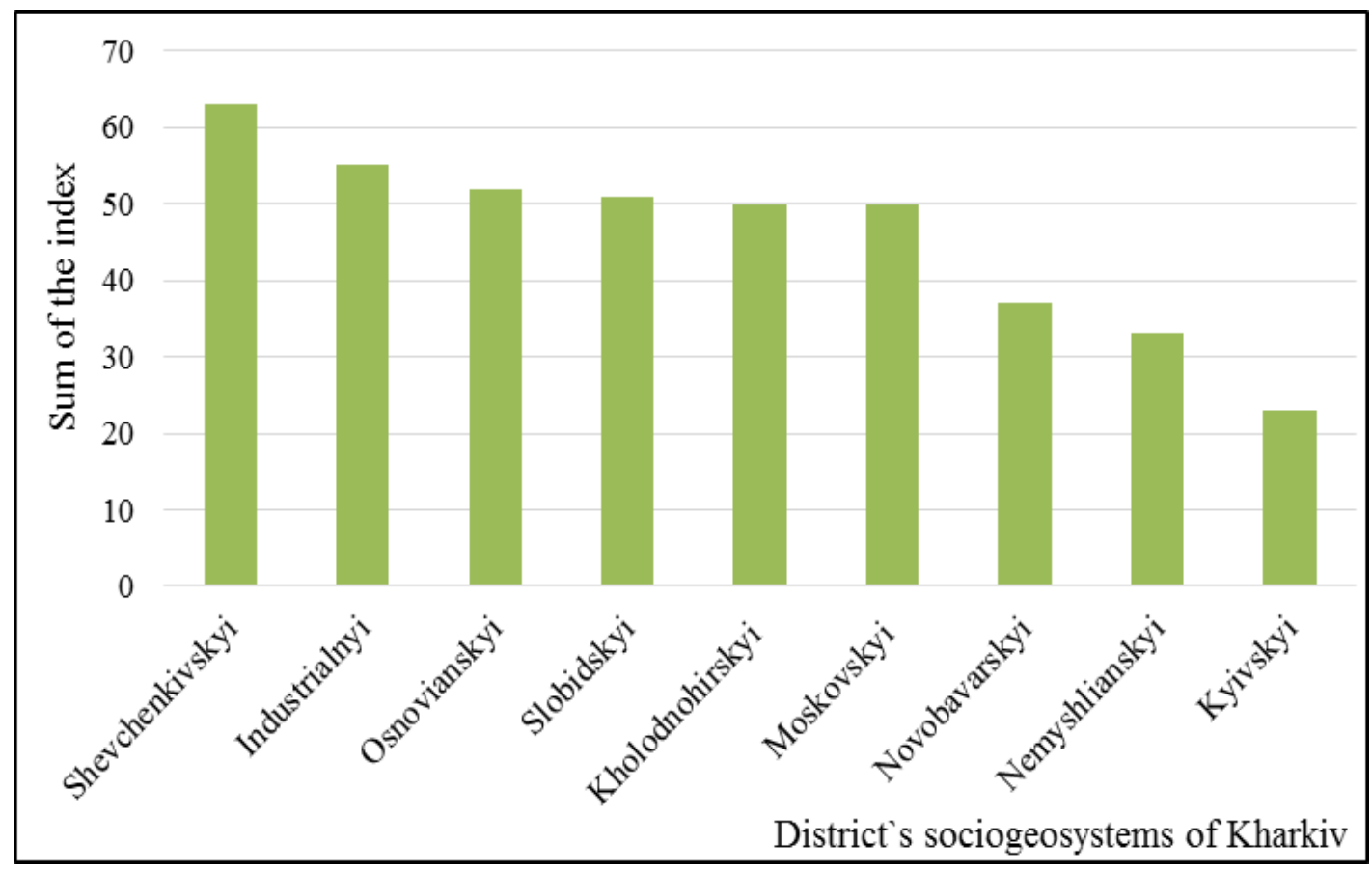

Fig. 2. Distribution of Kharkiv districts by the sum of codes for the period 2010-2015 (constructed by the author according to component analysis) 


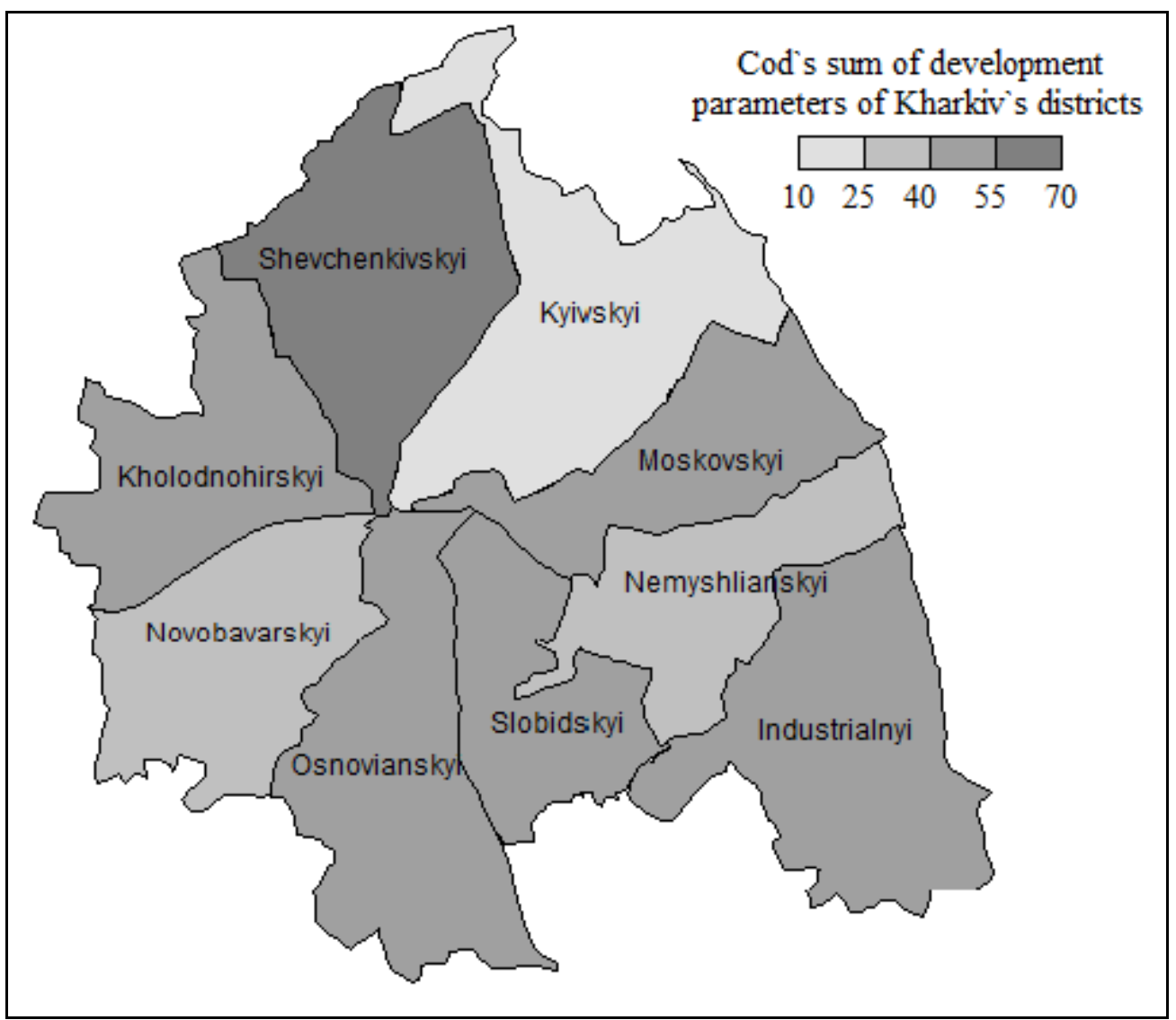

Fig. 3. Cod's sum of development parameters of Kharkiv districts for the period 2010-2015 (constructed by the author according to component analysis)

For Shevchenkivskyi and Kyivskyi districts the reduction in the number of school and pre-school establishments is typical with the general increase of births. It is proposed to increase the number of schools and pre-schools or to renew institutions that are currently not working. Also, it is proposed to update the infrastructure elements of institutions (athletic fields and swimming pools).

There is a decrease in the number of officially registered enterprises Nemyshlianskyi and Osnovianskyi districts. To support business development in these districts it is proposed to introduce partial tax cuts for business organizations, programs to support small and medium businesses.

Conclusions. During 2010-2015 development of Kharkiv SGS was positively influenced by the following factors: an increase in the number of children in preschools and other educational institutions; volumes of the sold industrial output; number of officially registered enterprises; reduction of boiler and oven fuel use; reduction of heat power use.

Decline in population, reduction of educational institutions and students at higher education institutions by III and III-IV levels; reduction in the number of workers engaged in scientific activity were negative factors for development of Kharkiv`s SGS.
For all research time Shevchenkivskyi and Kyivskyi districts were the leaders by all indicators. Nemyshlianskyi and Kyivskyi districts were outsiders by dynamics of development.

For Novobavarskyi, Slobidskyi, Kholodnohirskyi, Osnovianskyi and Nemyshlianskyi districts it is proposed to introduce programs for improving the demographic situation (increase of additional payments for the birth of a child and its maintenance, development of a network of establishments for children of school and preschool age).

For Shevchenkivskyi and Kyivskyi districts it is proposed to increase the number of schools and preschools or to renew institutions that are currently not working, update the infrastructure elements of institutions (athletic fields and swimming pools). For Nemyshlianskyi and Osnovianskyi districts it is proposed to support business development (partial tax cuts for business organizations, introduction of programs to support small and medium businesses).

By using the method of component analysis in this study, it was possible to identify the main problems of socio-economic and spatial development of the city, as well as to propose recommendations for its improvement. 


\section{References}

1. Мезенцев, К. В. Методи дослідження в суспільній географії: традииії і новації / К. В. Мезенцев // Економічна та соиіальна географія. - 2013. - Вип. 1(66). - C. 31- 42.

2. Місто Харків у 2010 р. (статистичний щорічник) / [під редакцією О.Г. Мамонтової]. - Х., 2011. - 175 с.

3. Місто Харків у 2011 р. (статистичний щорічник) / [під редакцією О.Г. Мамонтової]. - Х., 2012. - 186 с.

4. Місто Харків у 2012 р. (статистичний щорічник) / [під редакцією О.Г. Мамонтової]. - Х., 2013. - 182 с.

5. Місто Харків у 2013 р. (статистичний щзорічник) / [під редакиією О.Г. Мамонтової]. - Х., 2014. - 188 с.

6. Нємець, К. А. Методика інформаџійного аналізу соціально-економічного розвитку регіонів / K. A. Нємець, О. К. Немець // Матеріали міжнародної науково-практичної конферениї «Регіон - 2008: стратегія оптимального розвитку». - Харків : ХНУ. - 2008. - С. 242-246.

7. Немець, К. А. Просторовий аналіз у суспільній географії: нові підходи, методи, моделі : монографія / К. А. Немець, Л. М. Немецьь. - Харків : ХНУ, 2013. - 225 с.

8. Немеи, К. А. Статистические методы и обработка геоинформации: учебно-методическое пособие / K. A Немец., Е. Ю. Сегида. - Харьков : Харьковский национальный университет имени В. Н. Каразина, 2013. $60 \mathrm{c.}$

9. Немець, К. А. Теорія і методологія географічної науки: методи просторового аналізу / Навчальнометодичний посібник // К. А. Немець, Л. М. Немецьь. - Х. : ХНУ імені В. Н. Каразіна. - 2014. - С. 172.

10. Статистичний щзорічник «Міста та райони Харківськой області в 2010 роиі» [Електронний ресурс]. - Режим достуny: http://kh.ukrstat.gov.ua/index.php/statystychnyi-shchorichnyk-mista-ta-raiony-kharkivskoi-oblasti$v$-2010-rotsi

11. Статистичний щорічник «Міста та райони Харківської області в 2011 рочі» [Електронний ресурс]. - Режим доcmyny: http://kh.ukrstat.gov.ua/index.php/statystychnyi-shchorichnyk-mista-ta-raiony-kharkivskoi-oblasti$v$-2011-rotsi

12. Статистичний щорічник «Міста та райони Харківської області в 2012 роиі» [Електронний ресурс]. - Режим достуny: http://kh.ukrstat.gov.ua/index.php/statystychnyi-shchorichnyk-mista-ta-raiony-kharkivskoi-oblasti$v$-2012-rotsi

13. Статистичний щуорічник «Міста та райони Харківської області в 2013 роиіі» [Електронний ресурс]. - Режим достуny: http://kh.ukrstat.gov.ua/index.php/statystychnyi-shchorichnyk-mista-ta-raiony-kharkivskoi-oblasti$v$-2013-rotsi

14. Статистичний щ⿻орічник «Міста та райони Харківськой області в 2014 роичі» [Електронний ресурс]. - Режим достуny: http://kh.ukrstat.gov.ua/index.php/statystychnyi-shchorichnyk-mista-ta-raiony-kharkivskoi-oblastiv-2014-rotsi

15. Статистичний щорічник «Міста та райони Харківської області в 2015 роиі» [Електронний ресурс]. - Режим достуny: http://kh.ukrstat.gov.ua/index.php/statystychnyi-shchorichnyk-mista-ta-raiony-kharkivskoi-oblasti$v$-2015-rotsi

16. Статистичний щзорічник «Харківська область у 2015 роиіi» [Електронний ресурс]. - Режим доступу : http://kh.ukrstat.gov.ua

17. Топчієв, О. Г. Суспільно-географічні дослідження: методологія, методи, методика / О. Г. Топчієв. - Одеса, 2005. $-632 c$.

18. Шаблій, О. І. Математичні методи в соціально-економічній географії [навч. видання] / О. I. Шаблій. Львів : Світ, 1994. - 304 c.

19. Шаблій, О. І. Основи загальної суспільної географії [підручник] / О. І. Шаблій. - Львів : Видавничий иентр ЛНУ ім. Івана Франка, 2003. - 444 с. 